\title{
Infrastructures of utopia: ruination and regeneration of the African future
}

\author{
Ferdinand de Jong and Brian Valente-Quinn
}

\begin{abstract}
First, this time of African existence is neither a linear time nor a simple sequence in which each moment effaces, annuls, and replaces those that preceded it, to the point where a single age exists within society. This time is not a series but an interlocking of presents, pasts, and futures that retain their depths of other presents, pasts, and futures, each age bearing, altering, and maintaining the previous ones. (Mbembe 2001)
\end{abstract}

The site today known as Sebi Ponty situated outside Dakar, Senegal, has been the launch site of a number of infrastructural developments, including two large-scale educational initiatives: the École normale William Ponty and, more recently, the University of the African Future. These two projects articulated different visions for African futures, designed to spur increased economic development. Yet both fell short of their promise and left behind dilapidated infrastructures that constitute palimpsests of imagined Afro-futures. In this article, we examine how these infrastructures are incorporated today in an ambitious urban development, called the Pôle urbain de Diamniadio, a new city set upon the ruins of prior infrastructural initiatives. To investigate how the temporalities and materialities of these infrastructures are entangled, we conduct an archaeology of Sebi Ponty's ruins by excavating strata of abandoned futures and documenting the traces of the hope that these futures can yet be reclaimed.

Our concern with the ruin comes at a particular stage of modernity. ${ }^{1}$ The recognition of modernity's ruination emanates from a concern with this concept, so central to Eurocentric thinking, as a universal instrument of progress (Chakrabarty 2008; Enwezor 2010). Modernity's apparent failure to deliver on its promise of progress for all informs our critical attention to its conception (Ferguson 2006; Piot 2010). But critical reflexivity on modernity can be traced right to the moment when

Ferdinand de Jong is Senior Lecturer in Anthropology at the University of East Anglia. He has published widely on masquerading, memory, heritage and archives. He is currently completing a manuscript on Senegal's Pan-African heritage. Email: F.Jong@uea.ac.uk

Brian Valente-Quinn is Assistant Professor of French at the University of Colorado Boulder. $\mathrm{He}$ specializes in Francophone African literature and his current research explores sites and histories of stage performance in Senegalese theatre. Email: Brian.Quinn@colorado.edu

${ }^{1}$ This article draws on complementary expertise acquired in different academic careers. We conducted a research trip accompanied by the photographer Judith Quax, who took the photographs that accompany this article. In May-June 2013, we visited Sébikotane, where we met with local primary school teacher Malick Guèye, who introduced us to former employees of the École William Ponty and the University of the African Future. In Dakar, we were courteously received by the former project manager Papa Mohamed Camara, former President Wade, and former Minister Assane Seck. An earlier version of this article was published in French in a special issue of Politique Africaine (no. 135, October 2014), and we are grateful for the journal's permission to include parts of that article here. The present article broadens the focus on nostalgia by framing it within a wider discussion on infrastructures and their ruination. 
European imperialism created a context for the exportation of an ideology of progress through the civilizing missions of empire (Larkin 2008: 8). Critical accounts of colonial modernity, such as Joseph Conrad's stories told from the outposts of progress, have bracketed the achievements of this 'progress'. If, as Conrad shows, colonial modernity lay in ruins from its very onset, how might ruins help us think about the condition of Africa's modernity? How is infrastructure entangled with the imagination of the African future and its subsequent ruinations?

Rather than thinking of history as a story of linear progress, Walter Benjamin (1999: 249) conceived of modernity as an accumulation of ruins. In this imaginary, ruins are the result of ongoing modernization and progress is an illusion. Modern infrastructures nonetheless generated strong feelings of promise during the period of postcolonial independence (Barker 2005). But the deceptions of unrealized modernity have resulted in an experience of profound abjection, a sense that the future is beyond the potential of infrastructure's hold. This loss of a compelling vision of modernity has triggered the emergence of colonial nostalgia in a range of postcolonies (Bissell 2005; Buckley 2005). However, the nostalgias produced by ruination are plural and cannot be reduced to a singular experience (Berliner 2012; Lachenal and Mbodj-Pouye 2014). Accounting for parallel visions, various scholars have observed how infrastructural works represent promise and failure at the same time (Khan 2006; De Boeck 2011).

The discontents of modernity have led anthropologists to engage with matters of time, temporality and the possibilities of futures (Goldstone and Obarrio 2016). As archaeologists of modernity, anthropologists have started to excavate sites of infrastructure as traces of the futures that once were possible (Gordillo 2014; Geissler et al. 2016). Understood as a 'dialectical image' in Benjamin's sense, modern ruins can be studied as material evidence of the condition of modernity and should reveal the contradictions of progress (Dawdy 2010: 771). But how exactly should we conceive the relationship between materiality and temporality in a postcolonial modernity in which ruins have afterlives? Exploring the contours of an object-centred epistemology, some have argued that the materialities and temporalities are entangled in the very dilapidated structures that subjects inhabit (Fontein 2011; Navaro-Yashin 2012). But rather than assuming a foreclosed entanglement between materiality and temporality, we propose to prise open that relationship and examine how they are folded into each other. Indeed, if we understand ruination as a process (Stoler 2013), we will find that the reappropriation of ruins enables different temporalities of ruination and regeneration. In this article, we explore precisely these temporalities of ruination and regeneration at work in infrastructures in Senegal, as they generate affects of hope and despair among those who dwell in the ruins. Examining how different nostalgias are projected onto the broken bricks of Sebi Ponty and the concrete casts of the University of the African Future, we witness Afro-futures rising like phoenixes from the ashes of colonial modernity.

\section{One site, two futures}

Some 30 kilometres outside Dakar, adjacent to a site called Sebi Ponty, stand the remains of the University of the African Future (l'Université du Futur Africain) 


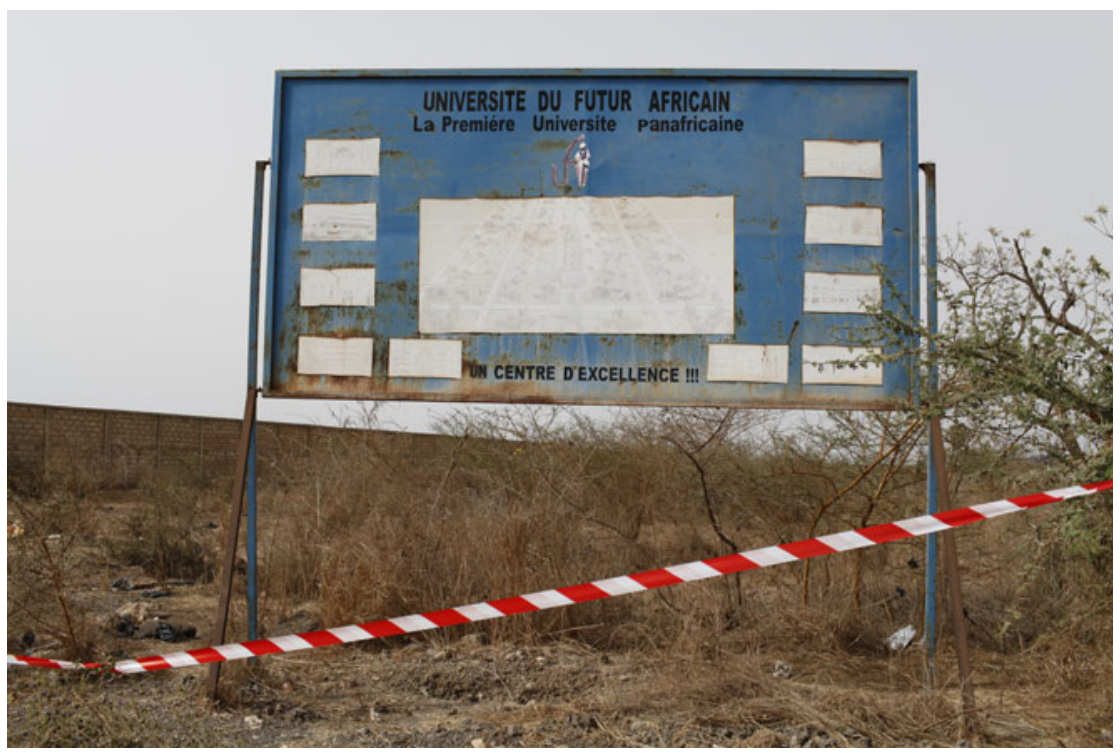

FIGURE 1 Sign indicating the construction of the University of the African Future on the road to Thiès. Photograph: Judith Quax.

(Figure 1), one of the many aborted construction projects of former president Abdoulaye Wade. Wade was inaugurated as the third president of Senegal when, after a life of political opposition, he finally succeeded in winning the presidential elections in March 2000. As the country celebrated the end of forty years of socialist rule, Wade initiated a liberal policy meant to realize his party's call for political sopi (change). In order to tackle the many challenges, the sociologist Momar Coumba Diop (2006: 111) states that:

It was important to give the people hope again, especially the young; to rebuild a moral economy that might promote a different path to societal development; to begin the cultural revolution carried forward by the life-changing utopias that emerged with Wade's rise to power.

The president initiated a policy of infrastructural works comprising the redevelopment of motorways in the congested capital Dakar, which re-energized the neomodernist belief in the nation's development (Melly 2013). While this gained him much credit, by the end of his first mandate the president had become known for an authoritative style, galloping governmental corruption and a lack of respect for the country's constitution (Dahou and Foucher 2004; Diop 2013; Bouilly and Brossier 2014). When ousted from power in elections in 2012, even the legacy of his infrastructural works was debated, most notably that of the controversial Monument of the African Renaissance, erected to celebrate fifty years of political independence, but considered by many a testimony to the bankruptcy of his politics (De Jong and Foucher 2010). 
In the case of the University of the African Future in Sebi Ponty, Wade's choice of location echoed, in multiple ways, a decision made early in the previous century to move to the same site the renowned William Ponty School, then the training grounds of an emerging African elite in the French colony. The palimpsestic reuse of the site of the Ponty campus, where the original vision of a governing regional elite was once housed, reflects the desire of Wade, himself a former Ponty student, or 'Pontin', to resurrect such visions of a prosperous African future in pursuit of his own Pan-African dream of a broad, continental network of institutions of higher learning for which his regime and educational background would serve as impetus and model. The Ponty campus, which stands within sight of today's abandoned University of the African Future, further serves as a reminder of Wade's Pan-African past, particularly in relation to his former political opponent Léopold Senghor, known for pursuing his education in France.

What, then, about the remote site of Sébikotane has caused this one location to serve twice as the geographic placeholder for dreams of an emerging Pan-African future? The answer to this question may lie primarily in the location and layout of the site. At the time of the Ponty School, administrators and educators were attracted to Sébikotane's remote and bucolic nature, which responded to a number of practical concerns as well as to a certain 'return to the soil' rhetoric popular in colonial approaches to so-called indigenous education. This was in contrast to the school's prior location on Gorée Island, known for its longstanding cosmopolitan culture and its proximity to Dakar. Decades later, such rhetoric would also prove useful to Wade's vision for a Pan-African system of higher education, which aimed to create an autonomous institution located away from the urban bustle of the capital.

But space and setting were not the only concerns pushing administrators to relocate the Ponty School to the more rural area of Sébikotane. The transfer, eventually completed in 1938, also corresponded with a paradigmatic shift in models of indigenous education in the French colonies. The colonial administration had begun adjusting its policies from a logic of assimilation to one of association, two key terms at the centre of a long debate among colonial educators (Conklin 1997; Segalla 2009). At stake was the very place of the French-educated African within colonial society. In the climate of Blaise Diagne's 1914 electoral victory and accession to the French Chamber of Deputies, a first for a black African, examples of successful integration into French culture foreshadowed a more forceful political role for the French-educated indigenous population. This pushed the colonial administration to rethink its educational approach and goals, as administrators quickly realized that, for the sake of economic return on colonial investment, they were less in need of Africans educated in the French republican tradition than of local artisans and agricultural workers. And although the Pontins were not destined for such work, it was imperative that they did not look down on the labouring professions, particularly in the remote, rural areas to which they were likely to be billeted as teachers or intermediaries (Jézéquel 2002). What was instead needed, administrators argued, was an enterprising ideal of a French-educated African deeply rooted in his indigenous identity, and thus able to relate to and influence the populations with which he came into contact, yet also sensible, logical, touched by a European deference to reason, a quality seen as sorely lacking in the native African mind. It was an ideal that called for a subtle approach to education in the upper levels of 
indigenous schooling, one that produced an elite that did not consider itself one. ${ }^{2}$ The goal of education at the competitive Ponty School was therefore described in the decades prior to the school's relocation by one of the leading proponents of 'adapted instruction', Director of Education Georges Hardy (1917: 173), as: 'To educate men for whom the outer world exists and who, modest and valiant, will go forward doing good.'

The school's new site at Sébikotane corresponded quite well with this new model. The remote nature of the location afforded a great deal of space for agricultural workshops and manual labour projects but included facilities such as an amphitheatre (Figure 2). Educators hoped to create an atmosphere similar to that of a large, autonomous, English-style campus. While students seemed to envision their education at Ponty as a step towards assimilation - or, more specifically, as a move towards the social benefits and rights of a legitimate claimant to full French citizenship - educators used the curriculum and location of the school to attempt to instil a rural identity, which was seen as being more in keeping with their traditional African roots. In this respect, the distance from Dakar offered by the Sébikotane site constituted one element of educators' attempt to associate, in students' minds, the benefits of an elite education with a rural lifestyle and outlook, characterized by a certain respect for and attachment to agricultural work and manual labour. The campus, which made use of abandoned military barracks located alongside the village of Sébikotane, soon took on a life of its own, becoming known as Sebi Ponty.

\section{The Pan-African legacy of the Ponty School}

The Ponty School's current ruined state reflects a controversial decision made in the early years of independence to move the institution in 1965 to Thiès, where its role was significantly diminished. This left behind a complex of neglected infrastructure which now houses two schools and a corrective facility. Despite this fall from grace, the highly selective nature of the Ponty School in its heyday ensured that a great number of the political and cultural elites who were to play prominent roles in the early decades of African independence were former Pontins. ${ }^{3}$

Among the most prominent of these in contemporary Senegal is Abdoulaye Wade, who looks back on his Ponty years with no small dose of nostalgia and clearly reflects what educators saw as the students' attachment to a claim on elite status by virtue of their connection to the school. In a 2012 interview on the topic of Ponty, the former president emphasized the elite status of what he called 'the most select of French schools', where students were engaged in a

\footnotetext{
${ }^{2}$ However, it is clear that, in many instances, the Pontins did consider themselves an elite. In an elegant formulation, Jézéquel puts it thus: 'Believing that their education distinguished them from the masses, the Pontins thought of themselves as an African and colonial elite called to participate, alongside the Europeans, in the "civilizing mission". Nevertheless, it is clear that the French consider "les pontins" to be an "indigenous elite" (Jézéquel 2005: 524-5).

${ }^{3}$ These include Félix Houphouët-Boigny, Mamadou Dia, Modibo Keïta and Bernard Dadié, among many others.
} 


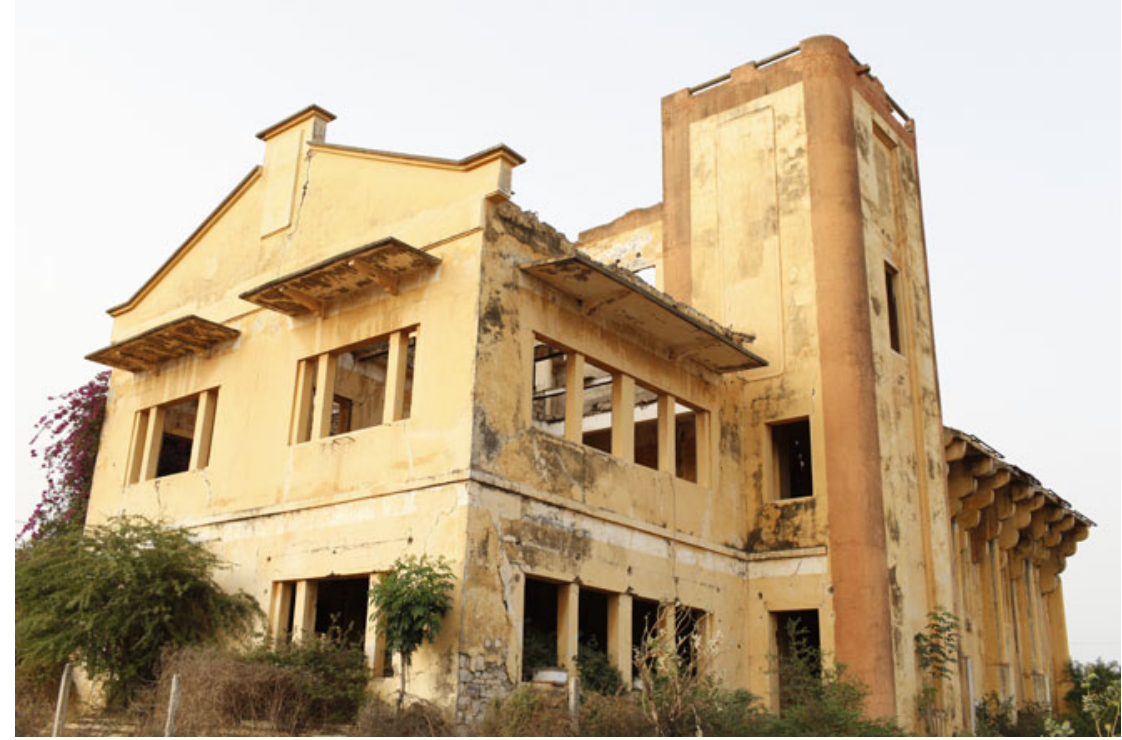

FIgURE 2 The ruined amphitheatre of the William Ponty School at Sebi Ponty. Photograph: Judith Quax.

rigorous study of French literature, 'which we knew like the back of our hands. It wasn't like today. We knew Corneille's Le Cid, Racine, Victor Hugo's Hernani.'4 Wade's focus on the literary component of his education is shared by many Ponty graduates, whose nostalgic memories of the school clash with the educators' attempts to downplay the elite, literary nature of their education.

The infrastructural project of the school's move to Sébikotane would in fact facilitate subsequent efforts by students and graduates to redefine the Ponty label for their own purposes. These later, curatorial efforts on the part of the former Pontins have included the formation of an alumni association (l'Association d'anciens élèves de l'École William Ponty), whose sole publication, Genèse, declared that 'the dream of a former Ponty student is not to be a caricature of a mind, but a true mind, in a true body'. 5 Prominent former Pontin Assane Seck, who was named Senegal's Minister of Culture in 1966 and remained in ministerial positions until 1983, attested in an interview to the sentiment of belonging to a privileged group in African society: 'Because the students felt chosen and ready to play an important role. I should also mention that we were among the best paid civil servants and the most respected in the villages.' It was apparently easy to capitalize on this status at the time:

We expected to play a role. We didn't have today's problems of 'What job am I going to have?' Once you arrived at William Ponty you were part of a section and if people knew

\footnotetext{
${ }^{4}$ Interview with Abdoulaye Wade, 4 July 2012.

${ }^{5}$ Genèse: Le Bulletin de L'Association William-Ponty, 1945, p. 78.
} 
you had completed your work you were certain to be hired. Straight away ... and you had a certain status. ${ }^{6}$

Seck further confirms the sentiment of solidarity found among former students of the Ponty School, who worked to maintain a connection with their fellow Pontins throughout the years and across the borders of French West Africa (Afrique Occidentale Française or AOF):

At the time when I left the establishment, you could travel through all of West Africa for free. You would go to a village and ask if there was a teacher ... if you didn't stay too long - two, three days - he would take you in as his guest.

Seck connects this presence and importance of a West African elite to Abdoulaye Wade's objective in creating his University of the African Future. 'It was Abdoulaye Wade who wanted to bring about the idea of an African school for the African elite.' Seck recognized the potential utility of creating a Pan-African network of teachers and administrators, much like at the time of Ponty, when the emerging elite once served a cohesive purpose in West African politics and society. 'It's true that we formed a kind of intellectual clan that followed what was happening and that distinguished itself a bit from the rest of the population.'

Reflecting on the role of such an elite, Seck compares his experience as a student with that of his time as a politician and minister in Senghor's government, concluding that such a sense of cohesiveness in solidarity was sorely lacking during the time of African independence. While many of the respective leaders of the newly autonomous nations were indeed once students of the prestigious West African school, the sense of a broader Pan-African unity of the type enabled by the network once maintained by former Ponty students was, to Seck's mind, sorely lacking.

Perhaps that's what was missing at the time of independence ... If we had forged the same unity as at William Ponty - and I should also mention that in each territory, the ones who ruled first were all from William Ponty: Houphouet-Boigny, everyone, all of the Francophone states went to Ponty ... So there was a Ponty mindset at the time. Perhaps by working first with that we could have formed a kind of united Francophone Africa. ${ }^{7}$

\section{The University of the African Future}

One finds reflections of this desire to construct a future-oriented intellectual elite in the language employed by Abdoulaye Wade and his collaborators in the later project for a University of the African Future (UAF). It was certainly with a utopian image of a Pan-African future in mind that the Senegalese president launched this new institution, to be built close to the ruins of the École normale William Ponty. To execute his dream of a world-class, Pan-African University of the Future, Wade would name, upon his election as president, Papa

\footnotetext{
${ }^{6}$ Interview with Assane Seck, 11 July 2012.

${ }^{7}$ Ibid.
} 
Mohamed Camara to lead the project and to serve as head of pedagogy. Camara was offered the position by virtue of his extensive experience studying abroad in several business schools in the US. He had also established a reputation for himself professionally through his role in a hardware mutualization project with the Senegalese electricity company Senelec and was reputed to speak more than ten languages, including American English. Camara did not know how many had preceded him in this post, but he did recollect that he was not the first - an illustration of Wade's contested policy of nominating an escalating number of advisers (conseillers) to high-power posts in an attempt to sustain his popularity through patrimonial politics. ${ }^{8}$

As a former Pontin himself, Wade had chosen Sébikotane as the site on which to revive what Camara called Ponty's 'spirit of excellence'. This sentiment was expressed explicitly in our interview with the former project manager, who explained: 'The idea is that Sébikotane has a location called Sebi Ponty, known for its spirit of excellence. It is the sparkle of excellence that the president wanted to capture, a kernel that the president wanted to regrow in the University of the Future.' The identification of a putative spirit of place highlights an attempt to deploy the collective memory of the colonial past in promotion of Wade's project of regeneration. Much like the Ponty School, the university was to offer a pedagogical programme that favoured practical skills and knowledge, this time with the goal of supporting a Pan-African ideal of economic development. The UAF was to serve African students with an education comparable to that of the best universities in the world. Project brochures and DVDs touted a diploma that would be on a par with world-class institutions such as the Harvard Business School, the Massachusetts Institute of Technology, or the Sorbonne. The spirit of radical equality envelopes the project's promotional literature, which takes care to point out that Africans are every bit as capable intellectually as their Western counterparts. All that is required to achieve academic excellence on the continent is to create the necessary conditions of possibility for competition. The brochure goes on to ask: 'Why not create in Africa the same study and development conditions for Africans to obtain the exact same degrees as Americans and Europeans and get the same job opportunities?'

In view of this goal, the brochure proposed collaborations with American and European universities, some of which, as we learned from Camara, Senegalese delegations had already visited, liaising with the Senegalese scholars working within these institutions. The courses at the UAF would be taught by the faculties of foreign institutions, thus ensuring quality comparable to the prestigious partner institutions and granting 'identical' weight and prestige to the university's credentials: 'The aim of this policy is to give the diplomas issued by this university a universal validity. These diplomas will be recognized as identical to those of the greatest academic institutions in the world.'

\footnotetext{
${ }^{8} \mathrm{We}$ had the opportunity to meet Camara for an interview that he kindly accorded us. During the interview, Camara gave us copies of the DVD and brochure made to promote the project, which have informed our understanding of it: Université du Futur Africain/University of the Future of Africa, brochure published by the Senegalese government, 33 pages, no date; Université du Futur Africain: un rêve devenu une réalité, DVD produced and realized by the Management of the University of the African Future, 11 minutes and 2 seconds, no date.

${ }^{9}$ Université du Futur Africain/University of the Future of Africa.
} 
As we learned from the brochure, it was hoped that the UAF could counter the effects of Africa's loss of human resources, lasting from the centuries of slave trade to the present-day mass emigrations of young students and entrepreneurs. Much like the former colonial school, whose 'spirit of excellence' the university hoped to rekindle, the new institution was meant to enroot Africa's brightest minds, ensuring that their education would benefit the continent. Much like the William Ponty School, the UAF aimed to provide the continent with the doctors, engineers and technocrats needed to steer Africa towards the elusive goal of economic development. Rather unlike Ponty, but in keeping with the school's subsequent legacy, the university would emphasize to students the elite nature of its diploma. Yet how such a diploma, especially a universally recognized one, might stop the brain drain from Africa was perhaps less well considered. Universalism has remained a utopian promise, its legacy still thwarted by the particular demands of local development. ${ }^{10}$

The curriculum to be offered by the UAF did not conform to the programmes of European or American universities. With no experience in university administration, Camara took as a model his own experience at American business schools: 'What I would do was close my eyes and think of the universities I attended in the US. ${ }^{11}$ It is no surprise, then, and certainly in keeping with Wade's vision, that he imagined the university as a school for business administration, with courses in chemical, agricultural and civil engineering, electronics and robotics, public administration, health management, and so on. In all of these courses, the focus would be on fostering the technical skills needed to address Africa's current economic woes, with an additional, somewhat incongruous programme - given that it seemed to constitute the sole humanities component offered in 'Advanced African Studies', to be hosted in what was called a 'House of History'.

While the Advanced African Studies programme was meant to instruct AfricanAmerican students in Africa's ancient civilizations, all other courses at the UAF aspired to prepare the continent for a global future. The logistics conceived to provide learning materials and courses reflected both the scarcity of resources and the tech-savvy focus of the project. The library would be devoid of books, but connected to the Bibliothèque François Mitterrand, the Library of Congress, the Tokyo General Library and American university libraries. Lectures would be streamed via internet 'in real time', allowing students to take courses delivered in Tokyo and New York from multimedia smart rooms on campus, and serving, effectively, to cancel, through a 'harmonization of real time', both the real-time difference separating the continents and, more figuratively, the 'temporal lagging' Homi Bhabha (1994: 364) identified as the postcolonial condition. ICT would permit students to 'catch up' with the

\footnotetext{
${ }^{10}$ Within the French imperial nation state, an ideological tension prevailed between universal humanism and a particular sense of belonging to a colonized race, as intellectuals of the Negritude movement were keen to articulate. This tension was never resolved in colonial policy and still prevails in Pan-Africanist ideas articulated by contemporary African politicians. For an insightful discussion of this tension in the colony, see Wilder $(2005 ; 2015)$.

${ }^{11}$ Interview with Papa Mohamed Camara, 12 June 2013.
} 
contemporary developed world in a gesture of temporalization inflected by utopian thinking. ${ }^{12}$

Ever the staunch Pan-Africanist, Abdoulaye Wade envisioned his new university as a fundamentally Pan-African institution that would serve as the founding campus of a network of universities housed in different sites throughout the continent. Other locations would eventually serve Central, East and Southern Africa. The North, Camara explained, was deemed sufficiently endowed so as not to require a campus of its own - but this exclusion undoubtedly also reflected historical complications in integrating the Arab North in Pan-African unification initiatives. The African diaspora in the United States would be courted through an African studies programme for students from the New World, often labelled Africa's 'sixth region' by President Wade. In short, in terms of the development goals it was meant to serve, the students it would recruit, and how the institution would fit within a wider programme for higher education in Africa, the UAF was a quintessential Pan-African project. ${ }^{13}$

Even if it were Pan-African in conception, Wade's plan drew ire from Dakar's University Cheikh Anta Diop (UCAD), whose administration was not consulted in its conceptualization, nor asked for assistance in its implementation. The most insulting part of the plan for the professors of UCAD was Wade's idea that African colleagues working abroad should be better equipped to deliver courses at the new elite institution - all the more so since these colleagues were seen as contributing to the brain drain that the UAF was intended to stop. If the president's autocratic style had previously upset the academic community, his megalomania further estranged his potential partners for this grand projet.

\section{A concrete future}

The campus of the University of the African Future was entirely designed by Pierre Goudiaby Atepa, a Senegalese architect who had been an adviser to Wade's government since its early days. ${ }^{14}$ Goudiaby's design combined features of African heritage with references to a range of architectural legacies. Although postmodernism was no longer in vogue at the time when the university was designed, Goudiaby's concept clearly recapitulates styles from different eras and geographies. In its appropriation of classical architecture, the design imagines the emerging African renaissance as inspired by classical civilizations. The campus

\footnotetext{
${ }^{12}$ Considering the limited technological resources in Senegal, it was perhaps inevitable that this project for a virtual university should fail. For another failed project of a virtual African university, see the analysis in Loiret (2008).

${ }^{13}$ In his Un destin pour l'Afrique, Abdoulaye Wade had called for an economic union of African states in the New Partnership for Africa's Development (NEPAD), with the aim of creating a United States of Africa (see Wade 2005).

${ }^{14}$ For a biography and overview of his major works, see <http://fr.wikipedia.org/wiki/ Pierre_Goudiaby_Atepa>, accessed 27 October 2016. A report published by IGE in 2014 found that the architect's office mismanaged the funding and multiplied its claimed expenses for the university's design without any governmental control (see 'Université du Futur Africain: la boulimie financière du Cabinet Atepa', Dakaractu, 30 July $2014<$ http://www.dakaractu.com/ Universite-du-Futur-Africain-la-boulimie-financiere-du-Cabinet-Atepa_a71720.html>, accessed 12 July 2017).
} 


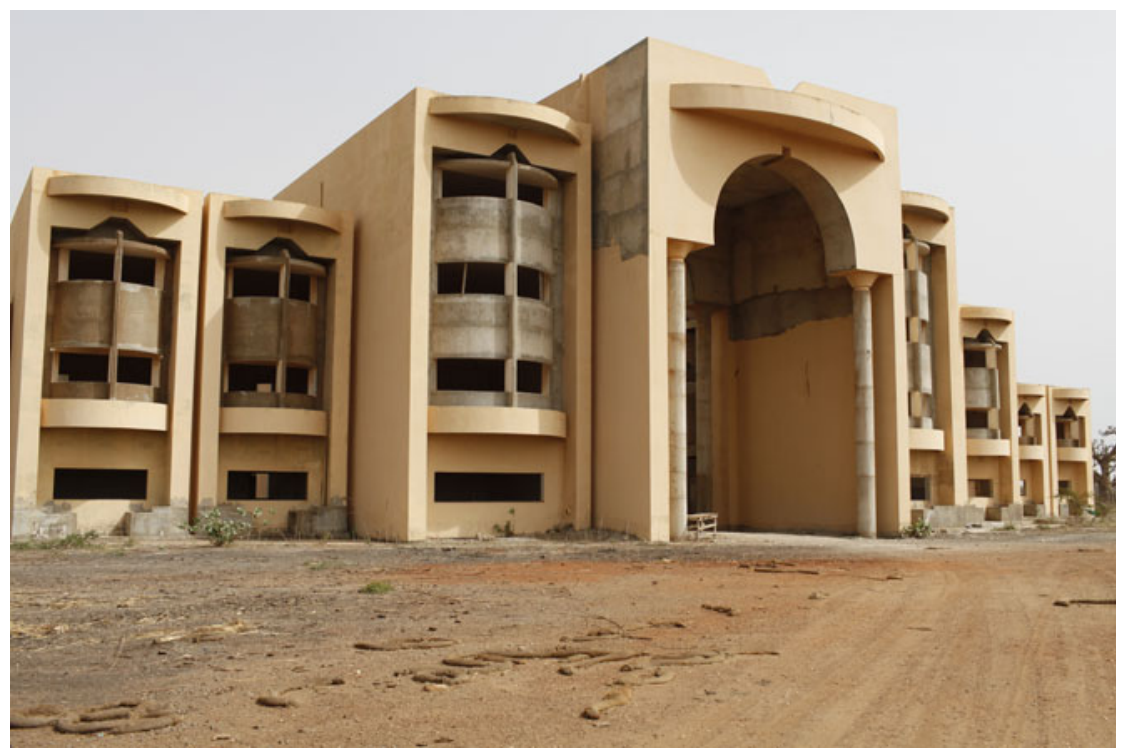

FIGURE 3 Administrative offices of the University of the African Future. Photograph: Judith Quax.

entrance is formed by an administrative building reminiscent in form of a Roman triumphal arch, here incorporating ancient Egyptian columns (Figure 3). Reached through the arch of the administrative building is the campus's main building, the central library, situated at the centre of the site (Figure 4). The library was designed in the conical shape of an inverted pyramid, symbolizing the knowledge accumulated throughout a student's career. The design of the UAF thus incorporates the Pan-African image of the pyramid, an ancient African symbol of gnosis, today accessed through digital connectivity. The reclamation of the legacy of Africa's civilization in the present is deliberately shaped in modern materials in order to meet the requirements of communication in the Third Millennium. Yet, at the heart of this utopian complex was an amphitheatre, incorporating a Greek legacy in a building bringing forth an African future, taken not so much from ancient Athens but from nearby Ponty, where the ancient amphitheatre still stands in the centre of the ruined buildings of the Ponty complex, covered with rampaging bougainvillea. (Few images capture the ruination of a colonial pedagogy better than this bougainvillea grown wild on the ruins of the amphitheatre.) The theatre, once a central meeting place of the Ponty School, was reinstated in the UAF, much like the seed of excellence in the mythical memory of the Ponty days replanted in the fertile soil of a renascent Sébikotane.

The University of the African Future was conceived as a Pan-African project and could not have been built had it not been for the assistance solicited and obtained from various friendly African heads of state. Camara recalled how each time a head of state would come to Senegal, the visit would include a full tour and progress report of the UAF building site, led by project manager 


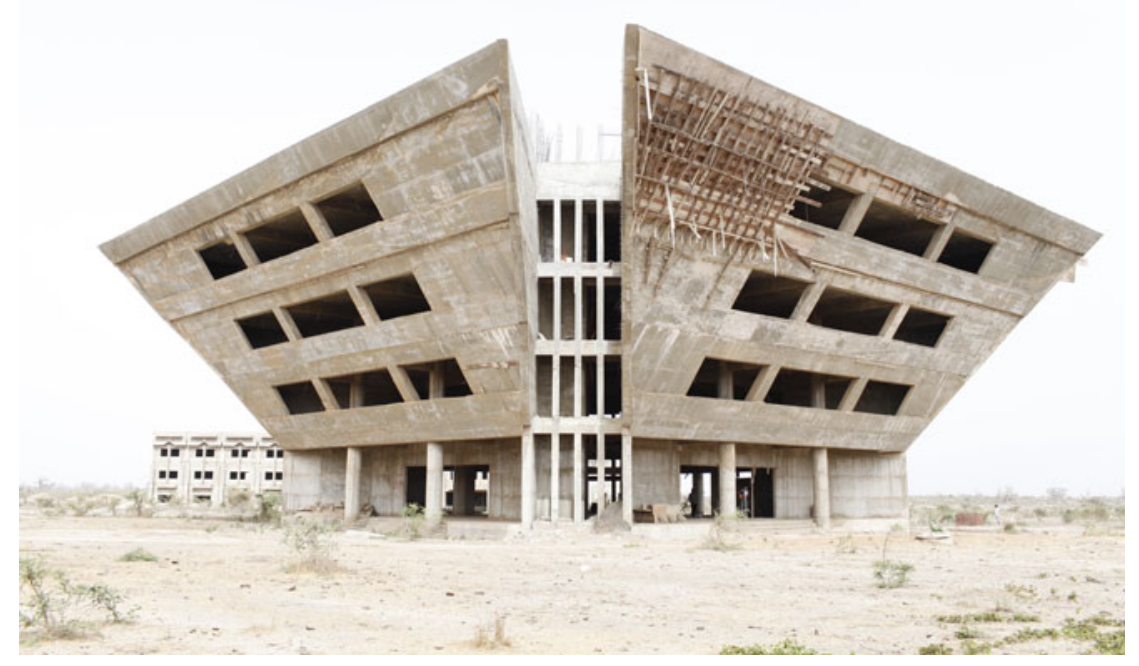

FIGURE 4 Central library of the University of the African Future. Photograph: Judith Quax.

Camara himself. Pavilion names on campus reflect the promised donations obtained in this manner. President Teodoro Obiang paid for the House of Equatorial Guinea, King of Morocco Mohamed VI funded the Grand Amphitheatre Hassan II, named after his father, and President Jacques Chirac funded the Pavilion Jacques Chirac. It was also hoped that the United Nations would fund the planned UN House. The promotional material also refers to the promised support from the United States as well as from international institutions such as the G8 and the European Union.

In order to make the university financially sustainable, Wade seems to have drawn partially from his memories of the colonial school at Sebi Ponty and its agricultural programmes. He envisioned a similar infrastructure for the university, including large workshops for agriculture, aviculture, animal husbandry and aquaculture. The successful exploitation of these workshops would lead to an economically sustainable and financially remunerative structure. Invoking the large-scale farms of a French supermarket chain, Camara envisioned the university as a utopian enclave:

We wanted to have a university that was a whole city. Sebi Ponty would have been a whole city, with a supermarket, with farms around it. Tractors belonging to the school would be used for agriculture, because the area is known for that. Because in that area there is a farm owned by Mr Filfily that produces its own produce - milk, carrots, cheese - it's like a big supermarket that produces its own produce; it exports cherry tomatoes. And they have a ranch. I was copying that, so that students would have their own supermarket and would have their own products. ${ }^{15}$

\footnotetext{
${ }^{15}$ Interview with Papa Mohamed Camara, 12 March 2013.
} 
But as the utopian funding structure of the university was put into place, the resources needed for its construction soon appeared problematic. During his first term in office, President Wade secured funding for the project from the Republic of Taiwan, which committed to financing the project with US \$16 million. A Lebanese corporation was commissioned and gradually built the large concrete buildings still standing today. But in 2005 the Senegalese Minister of Foreign Affairs, Cheikh Gadio, was approached by the People's Republic of China to rekindle international relations. President Wade seized the opportunity to re-engage relations with China, a move that jeopardized Taiwan's commitment to the UAF. Although construction work continued for some time afterwards, when funding from Taiwan was no longer forthcoming, the Lebanese construction company withdrew. Since 2006, the structures of the University of the African Future have stood waiting, appearing as if suspended in time, an ominous memorial to an ever emerging future.

\section{Afro-nostalgia}

When conducting our research at the former Ponty campus, we met several 'Pontés' - as the former personnel of Ponty called themselves, to be distinguished from the students, who are referred to as Pontins - some of whom now live in the houses of the former French teachers. Living in the ruins of Ponty, these people constitute a grass-roots curatorial community in commemoration of the utopian community Ponty represents for them today. In our interviews, they recalled the school as an orderly institution whose students obeyed their instructors, unlike Senegalese students today. When we recalled the strikes that students and the African workforce conducted at Ponty, the former manager of personnel remembered that there had been some 'disturbances', but these, he assured us, never lasted very long. In the memory of those who had worked in the school, Ponty had always been an institution of exemplary discipline. As a former washerwoman remembered: 'When the school was functioning, there was order and work. But ever since it has been abandoned, it has been a mess." 16 These elderly employees remembered serving an all-white teaching staff, a colonial relationship which they saw no reason to contest, then as now. No hint that the composition of the school's workforce exemplified the racism of colonialism passed their lips. Instead they referred to Ponty as paradise on earth ('le paradis sur terre'), precisely because of the patriarchal attitude of les blancs, whose 'kind generosity' they fondly remembered. Its former personnel wistfully remembered how well Ponty had been cared for; its well-tended trees, its shadowy lanes, its irrigation channels ... contrasting this lush garden of Eden with the desiccated landscape and dusty ruins of today's Ponty.

While our informants mourned the passing of the colonial order - and tears were shed - their nostalgia was not for white domination. Instead, it was inflected with Pan-African connotations, remembering the African presidents who had studied at Ponty rather than the French teachers. ${ }^{17}$ The nostalgia felt

\footnotetext{
${ }^{16}$ Interview with Awa Diallo, 7 June 2013.

${ }^{17} \mathrm{On}$ the complex interweaving of 'multiple nostalgias' in postcolonial contexts, see Bissell (2005), Berliner (2012) and Lachenal and Mbodj-Pouye (2014).
} 
by personnel of Ponty was, in fact, for the cosmopolitan gathering of the most talented students from the French colonies in one place, Ponty, where all of them were trained - anachronistically remembered - to serve their future independent countries. Ponty was invoked as a miniature of Africa (' $L$ 'Afrique en miniature'), a Pan-African university avant la lettre. The 'Pontés' were nostalgic for the Africa that should have emerged after independence but did not. Their colonial nostalgia was fundamentally utopian in its palimpsestic remembrance of colonial pasts and African futures.

Living amidst the decaying ruins of the École normale, the inhabitants of Ponty are intimately familiar with the experience of a lost future. In the tragic account of the project of the university given to us by its former project manager, the losses caused by the ruination of the École normale William Ponty and the University of the African Future merged in a generic sense of abjection. The project manager was born in today's Sebi Ponty village and had had a career in oil drilling before he was employed to oversee of the construction project of the UAF in 2000. In an interview he kindly accorded to us, the project manager sketched the development of the project of the UAF as he had experienced it. As part of his role, he had trained many co-villagers as masons and had been able to offer them employment. For several years the village had flourished as many of its youth had learned skills, but, as of 2006, the workforce was made redundant. Although many of the former workers were still employed elsewhere - thanks to the skills acquired during the building of the university - the project manager regretted that his life project had fallen into ruins. Unable to fund his own son's studies at the University of Dakar, he was visibly moved that the university in which he had invested so much would never be realized. He lamented the lack of care for the ruined infrastructures of Ponty, which should have been preserved; this failure to preserve the ruins of Ponty is echoed in the arrested construction of the university. Thus the Pan-African legacy of Ponty was neglected in the lack of care for its remnants, and is neglected once again at the university:

Well, you see, I think this is an opportunity to explain to you that this is the same suffering. It's the same suffering. ${ }^{18}$

\section{La nouvelle ville}

When given a guided tour through its ruins, we stumbled upon discarded temporalities, scattered around the grounds of Ponty. The social life of Ponty is constituted by age groups, each of them seeking out foreign donors to attract capital to the village in order to repair a school building, add another classroom, fund an arts festival, and so on. Ponty is saturated with temporalities of promise, as the seeds sown by the school keep on sprouting in the village's fertile soil. Some of these promises have affected young people who never attended Ponty themselves, but who have lived in the shadows of its nostalgic remembrance. Our guide in the village, a primary school teacher who had established his home

\footnotetext{
${ }^{18}$ Interview at Sebi Ponty, 7 June 2013: 'Bon, vous voyez, je pense que c'est une occasion de vous expliquer, mais c'est la même souffrance. C'est la même souffrance.'
} 
here, could not be defeated by the ruins of Ponty or the UAF. His optimism was inspired by sustained personal and symbolic investment in the continued reworkings of the Senegalese government's ongoing plans for the region. Imagining a modernist future for the derelict village, our guide claimed a new functionality for Ponty based on this shifting geography. Ponty, he said, is 'the gateway to Dakar' ('la porte de Dakar'). Walking through the dusty rubble of the ruined village, he prophesied: 'Here is the future' ('Ici, c'est l'avenir'). ${ }^{19}$

To see Africa's future rising, our guide Malick did not have to look very far. Since the beginning of our fieldwork in 2012, the site has become surrounded by an emerging new network of intercity highways, proof that, though initiated by Wade, the infrastructural development of the area will last beyond the former president's reign. Current President Macky Sall's promotion of a new city just adjacent to Sebi Ponty represents an attempt to continue previous infrastructural innovations without valorizing the vision of his political opponent and predecessor. The site, which is called the Pôle urbain de Diamniadio and is situated east of the conglomerate Dakar and its suburban extensions, is meant to reconstitute the gravitational field of the capital by alleviating the pressures on its colonial infrastructures established in the early twentieth century, shifting its centre of gravity eastward (Rao 2009: 26; Simone 2004). Dakar's expansion to the east has been ongoing since unanticipated population growth led to the construction of unregulated neighbourhoods (quartiers spontanés), devoid of the infrastructural facilities that were the hallmark of the planned suburban extensions of a city that could not keep up with demands for affordable housing in the banlieues (Sané 2013). Planned as a new infrastructural hub, Diamniadio is located between Dakar and the new Blaise Diagne International Airport, and is meant to provide a diverse range of housing opportunities, from social housing to modern high-rise apartments, all within reach of nearby cities. With further extensions of the toll highway to Thiès and Mbour, the press - with a sense of drama termed the emergent gravitational field 'the triangle of the new modernity'. ${ }^{20}$

With an economic budget expanding due to unprecedented levels of borrowing, Senegal's government is capitalizing on its economic and political stability and converting its relative security for the employees of international NGOs into unchecked expansion of its infrastructure. The World Bank, keen on infrastructural innovations, supported President Wade's bold step to shift the centre of gravity of the colonial infrastructure to a new constellation centred on a new airport. Incorporating it in his 'Emerging Senegal Plan' (Plan Sénégal Emergent or PSE), Macky Sall fully adopted his predecessor's ambitious plans and, in the spirit of neoliberalism, opened up the funding and construction of all the new infrastructures to public-private partnerships. 'Construisons le Sénégal avec Macky' ('Let's build Senegal with Macky') exhorted billboards throughout the region in reference to the new construction site, in a vein that departed only slightly from Wade's appeal to yesteryear notions of Pan-African greatness in favour of a revised, neoliberal image focused on economic development. Aspiring to 'replace society with the market, to build a universe out of aggregated transactions' (Comaroff and Comaroff 2000: 305), the neoliberal variant of urban

\footnotetext{
${ }^{19}$ Interview with Malick Guèye, 7 June 2013.

${ }^{20}$ Le Soleil, 7 June 2016.
} 
planning taps into global flows of capital to fund the 'Emerging Senegal'. Another future is taking shape, this time mediated through fast money mobilized through global finance-scapes.

Dubbed Diamniadio Valley, the new city is not merely designed to alleviate Dakar's heated property market by offering social housing; first and foremost, it is conceived as a site where new economic activities will develop. A study by the African Development Bank assessed the feasibility of a digital park that should ensure Senegal's alleged status as regional champion in the deployment of ICT. In 2016, the telecommunications company Tigo announced the establishment of a data centre that will offer secure digital data storage. The National Archives, which have been integrated within UNESCO's Memory of the World project, have announced a plan to establish storage space in Diamniadio. Accommodating such prestigious infrastructure alongside economic enterprises, the new city acquires the status of a postcolonial lieu de mémoire.

Due to long-standing pressures on the infrastructure of the University Cheikh Anta Diop, the 'Emerging Senegal Plan' envisions an expansion of institutions of higher education in Senegal's regions, including the establishment of a second campus of the University of Dakar in Diamniadio. The University AmadouMahtar M'Bow, named after the Senegalese Director-General of UNESCO (1974-87), will be housed in the new city and will accommodate faculties for sciences and technologies, health, economy and management. Like its predecessor, the University of the African Future, it aims to combine excellence in research and training and hopes to attract the best-qualified staff to deliver practical skills to students. However, unlike its predecessor, the University Amadou-Mahtar M'Bow was conceived as an extension of the University Cheikh Anta Diop, part of a national - rather than Pan-African - infrastructure for higher education, confirming Dakar in a competitive neoliberal spirit as the educational hub of the sub-region.

Erasing from memory the failed project for a University of the African Future now repurposed to house a national institute for petrol and gas - by initiating a national infrastructure of higher education, President Sall hoped his bid would be welcomed by the mass of unemployed students. Yet, even if the current generation of students has forgotten the promise of a University of the African Future, the memory of broken promises is well archived in Senegal's public sphere. As the Minister of Education announced that the University Amadou-Mahtar M'Bow would open by 2017 and press reports showed that the foundations had only just been laid, the public's response was sceptical to say the least. Knowing that construction works tend not to be completed on time, one commentator on Seneweb stated: 'Arrêtez de mentir au Sénégalais SVP' ('Please, stop lying to the Senegalese people'). Nostalgia for a Pan-African future is giving way to impatience with the realization of its neoliberal alternative: a future not yet past.

\section{On the horizon}

Appropriating a site of imperialist pedagogy for a project of Afro-modernist development, President Wade projected his nostalgia for an elite education onto the University for the African Future, but this infrastructural project failed to 
materialize the Afro-modernity once promised by the Ponty School. Today, the site of Sebi Ponty constitutes a palimpsest of Afro-futures in various degrees of ruination. In their entangled present, these temporalities of ruination remind the inhabitants of Sebi Ponty of the continuing corruption of Senegal's political culture. For the former employees of Ponty, the postcolonial ruination of the school reminds them that the present does not live up to the expectations they once held of the future. In their colonial nostalgia, the inhabitants used the diacritics of modernity to criticize the present (Bissell 2005). Indeed, in his reminiscences on the conditions of possibility of a Pan-African future at the moment of independence, former minister and former 'Pontin' Assane Seck contemplated what could have been done to realize a Pan-African modernity. This confirms that Afro-nostalgia has a utopian element, as it points to 'the possible futures that never came to be' (Boym 2010: 59). The nostalgia generated by ruined infrastructures informs a longing for another future, and another elite to realize the future so far denied to Senegal.

Examining the intersection of materiality and temporality of the sites, one might argue that the ruins of Sebi Ponty reveal a fracture between the decay one sees in the present and the hope the area now represents for the future. This fracture is certainly experienced at the building site of the University of the African Future by those Senegalese who remember the promises of a modernity they have seen slip away under successive independent governments. But the resurrection of Ponty's spirit in the UAF shows that postcolonial utopias can be engendered by the very colonial ruins that generated them in the first place. We need to acknowledge the optimism of our guide Malick, whose hope for the future was based on infrastructural plans for a new city. It is remarkable to what extent Sebi Ponty's location inspires hope for the future, alongside deep despair about Senegal's current predicament. Our own presence at the site was immediately taken as a sign of foreign interest in the potential redevelopment of the ruin. This gives us reason to think that the building site of the UAF bears comparison with the thousands of housing projects for Senegal's migrant population in the region of Dakar, which, although as yet unfinished, represent confident investments in the future (Melly 2010). Such confidence, which tends to be invested in private projects, is not necessarily extended to government-initiated infrastructural projects, which, as we saw, are received with distrust. This confirms Tousignant's (2013) argument that, in Senegal, a sense of crisis reinforces the feeling that futures are fragmented, rather than shared.

The utopian and dystopian images generated by the ruins emerge from temporalities of modernity that depart from linear conceptions of time. Ruined infrastructures may constitute critiques of the present yet they may also point to other, unanticipated futures. As infrastructures enable different futures, they point to a multiplicity of temporalities (Gordillo 2014: 225). Therefore, we feel that it would not be right to characterize nostalgia for modernity as an unambiguous sign of Africa's abyss. Modernity is not ruined; it consists of temporalities of ruination and regeneration that recapitulate and reinforce each other. Although its telos is hazy and its temporalities are fractured and contradictory, modernity's utopia is still firmly on Sebi Ponty's changing horizon. 


\section{Acknowledgements}

We would like to thank all our interlocutors, and Malick Guèye in particular, for their availability. We thank Judith Quax for her permission to publish the photographs in this article. Ferdinand de Jong expresses his gratitude to the British Academy for his Mid-Career Fellowship (MD120035) that funded his fieldwork. Brian Valente-Quinn's research was financed with a grant from the Mellon Foundation.

\section{References}

Barker, J. (2005) 'Engineers and political dreams: Indonesia in the satellite age', Current Anthropology 46 (5): 703-27.

Benjamin, W. (1999) 'Theses on the philosophy of history' in Illuminations. Translated by H. Zorn. London: Pimlico.

Berliner, D. (2012) 'Multiple nostalgias: the fabric of heritage in Luang Prabang (Lao PDR)', Journal of the Royal Anthropological Institute (N.S.) 18 (4): 769-86.

Bhabha, H. K. (1994) The Location of Culture. New York NY: Routledge.

Bissell, W. C. (2005) 'Engaging colonial nostalgia', Cultural Anthropology 20 (2): $215-48$.

Bouilly, E. and M. Brossier (2014) 'Senegal' in A. Mehler et al. (eds), Africa Yearbook Volume 10. Leiden and Boston MA: Brill.

Boym, S. (2010) 'Ruins of the avant-garde: from Tatlin's Tower to paper architecture' in J. Hell and A. Schönle (eds), Ruins of Modernity. Durham NC: Duke University Press.

Buckley, L. (2005) 'Objects of love and decay: colonial photographs in a postcolonial archive', Cultural Anthropology 20 (2): 249-70.

Chakrabarty, D. (2008) Provincializing Europe: postcolonial thought and historical difference. Princeton NJ: Princeton University Press.

Comaroff, J. and J. L. Comaroff (2000) 'Millennial capitalism: first thoughts on a second coming', Public Culture 12 (2): 291-343.

Conklin, A. (1997) A Mission to Civilize: the republican idea of empire in France and West Africa: 1895-1930. Stanford CA: Stanford University Press.

Dahou, T. and V. Foucher (2004) 'Le Sénégal, entre changement politique et révolution passive. "Sopi" or not "Sopi"?', Politique Africaine 96: 5-21.

Dawdy, S. L. (2010) 'Anthropology and the ruins of modernity', Current Anthropology 51 (6): 761-93.

De Boeck, F. (2011) 'Inhabiting ocular ground: Kinshasa's future in the light of Congo's spectral urban politics', Cultural Anthropology 26 (2): 263-86.

De Jong, F. and V. Foucher (2010) 'La tragédie du roi Abdoulaye? Néomodernisme et renaissance africaine dans le Sénégal contemporain', Politique Africaine 118: 187-204.

Diop, M.-C. (2006) 'Le Sénégal à la croisée des chemins', Politique Africaine 104: $103-26$.

Diop, M.-C. (ed.) (2013) Le Sénégal sous Abdoulaye Wade: le Sopi à l'épreuve du pouvoir. Dakar and Paris: CRES and Karthala.

Enwezor, O. (2010) 'Modernity and postcolonial ambivalence', South Atlantic Quarterly 109 (3): 594-620. 
Ferguson, J. (2006) Global Shadows: Africa in the neoliberal order. Durham NC, Duke University Press.

Fontein, J. (2011) 'Graves, ruins, and belonging: towards an anthropology of proximity', Journal of the Royal Anthropological Institute 17 (4): 706-27.

Geissler, P. W., G. Lachenal, J. Manton and N. Tousignant (2016) Traces of the Future: an archaeology of medical science in Africa. Chicago IL: Intellect and University of Chicago Press.

Goldstone, B. and J. Obarrio (eds) (2016) African Futures: essays on crisis, emergence, and possibility. Chicago IL: University of Chicago Press.

Gordillo, G. R. (2014) Rubble: the afterlife of destruction. Durham NC and London: Duke University Press.

Hardy, G. (1917) Une Conquête Morale: l'enseignement en A.O.F. Paris: A. Colin.

Jézéquel, J.-H. (2002) “"Les mangeurs de craies”. Socio-histoire d'une catégorie lettrée à l'époque colonial. Les instituteurs diplômés de l'École normale William Ponty'. PhD thesis, EHESS, Paris.

Jézéquel, J.-H. (2005) 'Les enseignants comme élite politique en AOF (19301945). Des “meneurs de galopins" dans l'arène politique', Cahiers d'Études Africaines 178: 519-44.

Khan, N. (2006) 'Flaws in the flow: roads and their modernity in Pakistan', Social Text 24 (89): 87-113.

Lachenal, G. and A. Mbodj-Pouye (2014) 'Restes du développement et traces de la modernité en Afrique', Politique Africaine 135: 5-21.

Larkin, B. (2008) Signal and Noise: media, infrastructure, and urban culture in Nigeria. Durham NC: Duke University Press.

Loiret, P.-J. (2008) 'L'université virtuelle africaine, l'enseignement à distance en trompe l'oeil?', Distances et Savoirs 6 (2): 187-209.

Mbembe, A. (2001) On the Postcolony. Berkeley CA: University of California Press.

Melly, C. (2010) 'Inside-out houses: urban belonging and imagined futures in Dakar, Senegal', Comparative Studies in Society and History 52 (1): 37-65.

Melly, C. (2013) 'Ethnography on the road: infrastructural vision and the unruly present in contemporary Dakar', Africa 83 (3): 385-402.

Navaro-Yashin, Y. (2012) The Make-Believe Space: affective geography in a postwar polity. Durham NC: Duke University Press.

Piot, C. (2010) Nostalgia for the Future: West Africa after the Cold War. Chicago IL: Chicago University Press.

Rao, V. (2009) 'Urbanism beyond architecture: African cities as infrastructure', African Cities Reader 1 (1): 23-40 <http://www.africancitiesreader.org.za/ reader.php\#acr3>.

Sané, Y. (2013) 'La politique de l'habitat au Sénégal: une mutation permanente', Les Cahiers d'Outre-Mer 263: 311-34.

Segalla, S. D. (2009) The Moroccan Soul: French education, colonial ethnology and Muslim resistance, 1912-1956. Lincoln NE: University of Nebraska Press.

Simone, A. (2004) For the City Yet to Come: changing African life in four cities. Durham NC and London: Duke University Press.

Stoler, A. L. (2013) 'Introduction. "The rot remains": from ruins to ruination' in A. L. Stoler (ed.), Imperial Debris: on ruins and ruination. Durham NC and London: Duke University Press. 
Tousignant, N. (2013) 'Broken tempos: of means and memory in a Senegalese university laboratory', Social Studies of Science 43 (3): 729-53.

Wade, A. (2005) Un destin pour l'Afrique. L'avenir d'un continent. Neuilly-surSeine: Éditions Michel Lafon.

Wilder, G. (2005) The French Imperial Nation-State: Negritude and colonial humanism between the two World Wars. Chicago IL and London: Chicago University Press.

Wilder, G. (2015) Freedom Time: Negritude, decolonization and the future of the world. Durham NC and London: Duke University Press.

\begin{abstract}
Ruination has recently received much attention as a defining aspect of the materiality of modernity. Less attention is given to the processes of regeneration that occur within sites of ruination. In this article, we examine how processes of ruination and regeneration are folded into each other, by looking at the materiality of a single site, a small village in the vicinity of Dakar, Senegal. By building the University of the African Future at Sébikotane, the Senegalese president has sought to rekindle the spirit of excellence that inspired education at the École normale William Ponty in a Pan-African spirit. As part of a larger plan for urban expansion, the site of Sébikotane has inspired hope for development. Examining how the different temporalities of utopian modernism and Afro-nostalgia intersect in the ruined site, this article reflects on the ruination of African futures on a site of ever renascent utopian infrastructures.
\end{abstract}

\title{
Résumé
}

Si les ruines sont souvent décrites comme un élément clé de la modernité dans son aspect matériel, on prête moins attention aux processus de régénération qui peuvent avoir lieu sur leurs sites. Ici nous examinerons les processus de ruines et de régénération dans leurs entrelacements en nous penchant sur un site particulier : un petit village aux alentours de Dakar, au Sénégal. En construisant l'Université du Futur Africain à Sébikotane, le président sénégalais tentait de réanimer, dans une logique panafricaine, l'esprit d'excellence qui avait inspiré l'éducation fournie à l'École normale William Ponty. Dans le cadre d'un plan d'expansion urbaine plus étendu, le site de Sébikotane inspire aujourd'hui de nouveaux espoirs de développement. En examinant le croisement de diverses temporalités de modernisme utopique et d'Afro-nostalgie présentes sur ce lieu en ruines, nous porterons une réflexion sur les ruines des futurs africains, interposées entre des infrastructures utopiques toujours renaissantes. 